\title{
Article \\ Phytoplankton Composition and Their Related Factors in Five Different Lakes in China: Implications for Lake Management
}

\author{
Junmei Jia ${ }^{1, *}$, Qiuwen Chen ${ }^{2,3, *}$, Haidong Ren ${ }^{1,4}$, Renjie Lu ${ }^{5}$, Hui He ${ }^{1}$ and Peiwen Gu ${ }^{1}$ \\ 1 State Key Laboratory of Plateau Ecology and Agriculture, Qinghai University, Xining 810016, China; \\ mingqiangren@163.com (H.R.); hehui1113@sina.com (H.H.); gpw214206@163.com (P.G.) \\ 2 State Key Laboratory of Hydrology-Water Resources and Hydraulic Engineering, Nanjing 210029, China \\ 3 CEER, Nanjing Hydraulic Research Institute, Nanjing 210029, China \\ 4 Key Laboratory of the Northern Qinghai-Tibet Plateau Geological Processes and Mineral Resources, \\ Qinghai Geological Survey Institute, Xining 810012, China \\ 5 Jiangsu Suzhou Environmental Monitoring Center, Suzhou 215000, China; lurenjie990@163.com \\ * Correspondence: jiadao_mei@126.com (J.J.); qwchen@nhri.cn (Q.C.)
}

check for updates

Citation: Jia, J.; Chen, Q.; Ren, H.;

Lu, R.; He, H.; Gu, P. Phytoplankton Composition and Their Related Factors in Five Different Lakes in China: Implications for Lake Management. Int. J. Environ. Res. Public Health 2022, 19, 3135. https:// doi.org/10.3390/ijerph19053135

Academic Editors: Piotr Rzymski and Kenneth W. Cummins

Received: 20 December 2021

Accepted: 2 March 2022

Published: 7 March 2022

Publisher's Note: MDPI stays neutral with regard to jurisdictional claims in published maps and institutional affiliations.

Copyright: (c) 2022 by the authors. Licensee MDPI, Basel, Switzerland. This article is an open access article distributed under the terms and conditions of the Creative Commons Attribution (CC BY) license (https:// creativecommons.org/licenses/by/ $4.0 /)$.

\begin{abstract}
In this paper, two trophic lakes: Lake Taihu and Lake Yanghe, and three alpine lakes: Lake Qinghai, Lake Keluke, and Lake Tuosu, were investigated to discover the connections between environmental factors and the phytoplankton community in lakes with differences in trophic levels and climatic conditions. Three seasonal data, including water quality and phytoplankton, were collected from the five lakes. The results demonstrated clear differences in water parameters and phytoplankton compositions in different lakes. The phytoplankton was dominated by Bacillariophyta, followed by Cyanobacteria and Chlorophyta in Lake Qinghai, Lake Keluke, and Lake Tuosu. It was dominated by Cyanobacteria (followed by Chlorophyta and Bacillariophyta in Lake Yanghe) and Cyanobacteria (followed by Chlorophyta and Cryptophyta in Lake Taihu). The temperature was an essential factor favoring the growth of Cyanobacteria, Chlorophyta, and Bacillariophyta, especially Cyanobacteria and Chlorophyta. The $\mathrm{pH}$ had significantly negative relationships with Cyanobacteria, Chlorophyta, and Bacillariophyta. Particularly, a high $\mathrm{pH}$ might be a strong and negative factor for phytoplankton growth in alpine lakes. A high salinity was also an adverse factor for phytoplankton. Those results could provide fundamental information about the phytoplankton community and their correlated factors in the alpine lakes of the Tibetan Plateau, contributing to the protection and management of alpine lakes.
\end{abstract}

Keywords: phytoplankton; environmental factors; connections; eutrophic lakes; alpine lakes

\section{Introduction}

The phytoplankton community, as a crucial primary producer, has profound influences on the geochemical cycling and the function of aquatic ecosystems [1]. In many eutrophic aquatic systems around the world, the phytoplankton community is dominated by several bloom-forming species, and the blooming of phytoplankton threatens those aquatic systems. Previous studies have suggested that the phytoplankton, dominated by cyanobacteria, affect the zooplankton structure and weaken the zooplankton biodiversity [2]. Additionally, the toxic species have adverse effects on other aquatic organisms, and the toxins accumulate in their body [3]. Thus, the exploration of environmental factors influencing the structure and dynamic of phytoplankton in eutrophic lakes has caught the attention of scientists worldwide [4-6]. Lakes located in Tibetan Plateau, such as Lake Qinghai, are neglected since they have low phytoplankton abundance and present no phytoplankton blooms. However, endemic fish and rare birds live in those lakes, and the alteration of the phytoplankton may affect the survival of rare fish and birds. Climate change may lead to a severe situation in those alpine lakes, as they are more susceptible to climate change. Therefore, it is critical 
to reveal phytoplankton structures and their driving factors in both trophic lakes and alpine lakes.

The factors affecting the growth of phytoplankton have been deeply explored in temperate and subtropical lakes. Temperature and nutrients are considered the most important factors regulating the growth of phytoplankton [1,7-9]. High temperature favors phytoplankton by increasing the growth rate and shifting the phytoplankton with higher optimum temperature species, such as cyanobacteria [10-12]. The effect of nutrients on cyanobacteria has been investigated in the long term. $\mathrm{P}$ has been identified as a limited nutrient factor in freshwater systems [13-16]. However, some buoyant species, including Microcystis, Cylindrospermopsis, Anabaena, Aphanizomenon, and Gloeotrichia, are not likely limited by $\mathrm{P}$, because the buoyant species can vertically migrate, consume excess phosphorus at the sediment-water interface, and then rise to the water surface to form blooms [17-21]. N is also a critical factor for the growth of cyanobacteria. $\mathrm{N}$ loading may promote Microcystis blooms by not only the enhancement of growth [22-25] but also the synthesis of protease inhibitors, discouraging zooplankton grazing [26,27]. Additionally, the $\mathrm{N}_{2}$-fixing cyanobacteria, such as Anabaena, Aphanizomenon, Aphanothece, Cylindrospermopsis, and Gloeotrichia, exhibit great flexibility in the $\mathrm{N}$ sources to form blooms and $\mathrm{N}$ fixation, making $\mathrm{N}$ sufficient to allow biomass to be continuously produced $[9,17,28,29]$. Temperature and nutrients are also essential factors for phytoplankton growth in high-latitude lakes [30,31]. A nine-year study of a mountain lake in Austria demonstrated that long-term phytoplankton changes were mainly attributed to the increasing temperature, while nutrients acted as modulating factors regulating the short-term phytoplankton changes [30]. A study of Lake Qinghai suggested that the increase in $\mathrm{P}$ load under climate change and overgrazing favored the growth of P-limited phytoplankton [31]. Nevertheless, some environmental factors such as salinity may have been neglected in the previous study. Considering that phytoplankton blooms are seldom reported in brackish lakes, the bloom-forming cyanobacterium is restricted in saltwater. However, freshwater blooms are found in many coastal areas [32,33]. Thus, salinity may not be a decisive factor in bloom formation. It is urgent to explore the potential factors influencing the phytoplankton community in both fresh and brackish lakes under climate change.

Lake Taihu and Lake Yanghe are eutrophic lakes located in subtropical and temperate areas, respectively. Lake Qinghai, Lake Keluke, and Lake Tuosu are alpine lakes located in the Tibetan Plateau. These five lakes have different climate conditions, presenting many differences in both environmental factors and the phytoplankton community. The comparisons between them could reveal the potential factors regulating the phytoplankton community. The exploration of the phytoplankton structure and the correlated factors is essential for understanding phytoplankton succession in different lakes, especially in the alpine lakes in the Tibetan Plateau. This study aimed to reveal the differences in phytoplankton communities of different lakes and explore the correlated factors regulating the growth of different phytoplankton phyla.

\section{Materials and Methods}

\subsection{Study Area and Sampling Locations}

Lake Taihu is located at the center of the Yangtze River Delta in Eastern China $\left(30^{\circ} 56^{\prime}-31^{\circ} 33^{\prime} \mathrm{N}, 119^{\circ} 56^{\prime}-120^{\circ} 54^{\prime} \mathrm{E}\right.$ ) (Figure 1), with an annual average air temperature of $15-17^{\circ} \mathrm{C}$. It has a surface area of approximately $2338 \mathrm{~km}^{2}$, a mean water depth of $1.9 \mathrm{~m}$, and a maximum depth of $2.6 \mathrm{~m}$ [34]. Lake Taihu serves as a critical water resource for drinking, irrigation, aquaculture, and many industries, as well as recreation and tourism. Nonetheless, Lake Taihu has suffered from high nutrient loads and eutrophication in recent decades [35].

Lake Yanghe is located in Qinhuangdao City in Northern China $\left(39^{\circ} 59^{\prime}-40^{\circ} 12^{\prime} \mathrm{N}\right.$, $119^{\circ} 10^{\prime}-119^{\circ} 15^{\prime}$ E) (Figure 1), with an annual average air temperature of $11^{\circ} \mathrm{C}$. It has a drainage area of $755 \mathrm{~km}^{2}$, a mean water depth of $5.7 \mathrm{~m}$, and a maximum depth of over $40 \mathrm{~m}$ ( $\mathrm{Li}$ et al. 2020). Lake Yanghe is a hydraulic project on the Yanghe River, supplies 
industrial and domestic water to Qinhuangdao City, and provides flood control for Funing Country and Beidaihe downstream. In recent years, nutrients from surface runoffs have greatly increased due to industrial and economic development in the area, leading to the continued outbreak of cyanobacterial blooms in the summer. This has negatively influenced its function as a drinking water source.

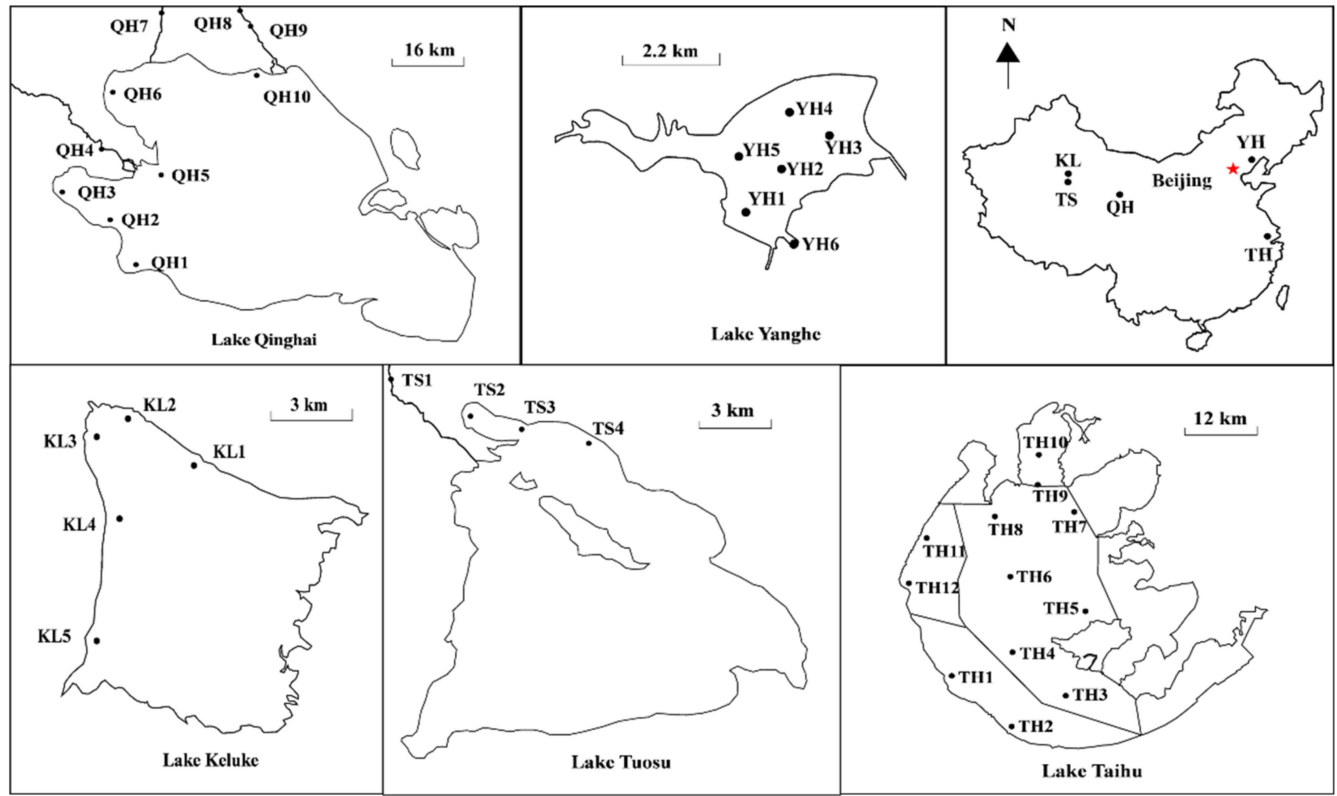

Figure 1. Sampling sites of Lake Qinghai, Lake Keluke, Lake Tuosu, Lake Taihu, and Lake Yanghe in China.

Lake Qinghai is located in Qinghai Province in Northwest China $\left(36^{\circ} 32^{\prime}-37^{\circ} 15^{\prime} \mathrm{N}\right.$, $99^{\circ} 36^{\prime}-100^{\circ} 47^{\prime} \mathrm{E}$ ) (Figure 1), with an area of about $4260 \mathrm{~km}^{2}$, a maximum depth of $30 \mathrm{~m}$, and a mean surface elevation of $3194 \mathrm{~m}[36,37]$. This area is characterized by an alpine and continental climate, with an annual average temperature of $1.2^{\circ} \mathrm{C}$ [37]. Lake Keluke $\left(37^{\circ} 15^{\prime}-37^{\circ} 20^{\prime} \mathrm{N}, 96^{\circ} 51^{\prime}-96^{\circ} 58^{\prime}\right)$ and Lake Tuosu $\left(37^{\circ} 04^{\prime}-37^{\circ} 13^{\prime} \mathrm{N}, 96^{\circ} 50^{\prime}-97^{\circ} 03^{\prime} \mathrm{E}\right)$ are located in Qinghai Province in Northwest China (Figure 1), with an annual average air temperature of $11^{\circ} \mathrm{C}$ [38]. Lake Keluke has an area of about $56.7 \mathrm{~km}^{2}$, a mean water depth of $4 \mathrm{~m}$, and a maximum depth of $13.3 \mathrm{~m}$. Lake Tuosu has an area of about $145 \mathrm{~km}^{2}$ and a maximum depth of $25 \mathrm{~m} \mathrm{[38].}$

\subsection{Sample Collection and Processing}

Water samples of five different lakes were taken in the spring, summer, and autumn. Water samples of Lake Taihu and Lake Yanghe were collected in the spring, summer, and autumn of 2014. Lake Taihu samples were collected from 12 locations (Figure 1) on 16 April, 22 July, and 24 September 2014. Lake Yanghe samples were collected from 6 locations (Figure 1) on 15 May, 21 August, and 14 October 2014. Water samples of Lake Qinghai, Lake Keluke, and Lake Tuosu were collected in the spring, summer, and autumn of 2018. Water samples of Lake Qinghai were collected on 28 and 29 May, on 20 and 21 August, and on 23 and 24 October from 10 sites (Figure 1). Water samples of Lake Keluke were collected on 1 June, on 18 August, and on 22 October from 5 sites (Figure 1). Water samples of Lake Tuosu were collected on 2 June, on 19 August, and on 22 October from 4 sites (Figure 1). Surface water samples $(2 \mathrm{~L})$ were taken at a $0.5-\mathrm{m}$ depth if the water depth was less than $2 \mathrm{~m}$ and were taken at $0.5 \mathrm{~m}, 1 \mathrm{~m}, 2 \mathrm{~m}, 3 \mathrm{~m}$, and $4 \mathrm{~m}$ if the water depth was less than $5 \mathrm{~m}$ [39]. All the samples were stored in polyethylene barrels at $4{ }^{\circ} \mathrm{C}$ in the dark before laboratory analysis. Water temperature, $\mathrm{pH}$, and salinity were measured in situ at each site using a YSI 6600 multi-probe sonde (YSI, Yellow Springs, OH, USA). An appropriate amount of water samples was filtered through GF/C glass fiber filters (Whatman, Kent, 
UK). Meanwhile, total nitrogen (TN) and total phosphorus (TP) were measured using the Chinese standard methods of HJ/T 636-2012 and GB/T 11983-1989, respectively.

Water samples $(100 \mathrm{~mL})$ taken from each sampling site were treated with Lugol's iodine solution to fix phytoplankton species. Phytoplankton was settled in $20 \mathrm{~mm} \times 20 \mathrm{~mm}$ chambers and identified/enumerated by light microscopy following commonly used monographs on phytoplankton [40,41]. The Shannon-Wiener index $(H)$ based on the number was calculated for phytoplankton [42]. The biodiversity of phytoplankton in the five lakes was calculated according to Bacillariophyta, Cyanobacteria, Chlorophyta, Cryptophyta, Pyrrophyta, Euglenophyta, and Chrysophyta.

\subsection{Statistical Analysis}

All data were statistically processed using SPSS 17.0 (SPSS, Inc., Chicago, IL, USA, 2008). The frequency of the water parameters and phytoplankton abundance approximated normal distributions. Pearson correlations were adopted to assess the relationships between environmental factors and phytoplankton. Additionally, the regression models were fitted to the water parameters and phytoplankton with significant relationships.

\section{Results}

\subsection{Water Parameters and Nutrients in the Five Lakes}

Table 1 exhibited the seasonal changes of the water parameters and nutrient levels. Lake Taihu had the highest average temperature of the three seasons, followed by Lake Yanghe, Lake Tuosu, and Lake Keluke, and lowest in Lake Qinghai $(p<0.05)$. The autumn had lower water temperatures than in the spring in the northern lakes, including Lake Qinghai, Lake Keluke, Lake Tuosu, and Lake Yanghe, with a higher temperature than that in the spring for Lake Taihu. Lake Qinghai and Lake Tuosu had the highest $\mathrm{pH}$ in the five lakes $(p<0.05)$, followed by Lake Keluke and Lake Taihu $(p<0.05)$. Lake Yanghe had the lowest $\mathrm{pH}$ in the five lakes $(p<0.05)$. There were significant differences in the salinity in the five lakes. Lake Tuosu had the highest salinity in the five lakes, followed by Lake Qinghai and Lake Keluke. Lake Taihu and Lake Yanghe had the lowest salinity in the five lakes. The inflow rivers had a lower temperature, $\mathrm{pH}$, and salinity compared to Lake Qinghai. This is also true in Lake Tuosu.

There was a clear seasonal pattern in TN in Lake Yanghe and Lake Taihu. The mean TN in Lake Yanghe were $2.7 \pm 0.02 \mathrm{mg} / \mathrm{L}, 0.1 \pm 0.01 \mathrm{mg} / \mathrm{L}$, and $0.5 \pm 0.1 \mathrm{mg} / \mathrm{L}$ in the spring, summer, and autumn, respectively. The mean TN in Lake Taihu were $2.8 \pm 0.7 \mathrm{mg} / \mathrm{L}$, $0.6 \pm 0.5 \mathrm{mg} / \mathrm{L}$, and $0.5 \pm 0.4 \mathrm{mg} / \mathrm{L}$ in the spring, summer, and autumn, respectively. The TP concentrations of the five lakes were all lower than $0.1 \mathrm{mg} / \mathrm{L}$. Lake Taihu, Lake Qinghai, and Lake Keluke had higher TP compared to Lake Yanghe and Lake Tuosu. There were not many differences in TP concentrations of Lake Keluke and Lake Tuosu in different seasons. There were clear seasonal differences in Lake Qinghai, Lake Taihu, and Lake Yanghe. The TN was higher in the inflow rivers than the main lakes of both Lake Qinghai and Lake Tuosu, while it had an opposite pattern about TP in the inflow rivers and the main lakes in the two lakes.

\subsection{Phytoplankton Composition and Biodiversity in the Five Lakes}

The composition of phytoplankton differed among the five lakes (Figure 2). The dominant phylum in Lake Qinghai, Lake Keluke, and Lake Tuosu was Bacillariophyta in the spring, summer, and autumn. In Lake Qinghai, the phytoplankton abundance was $3.7 \times 10^{5}$ cells $/ \mathrm{L}, 2.0 \times 10^{5}$ cells $/ \mathrm{L}$, and $1.5 \times 10^{5}$ cells $/ \mathrm{L}$. In the spring, summer, and autumn, Bacillariophyta accounted for $65 \%, 59 \%$, and $39 \%$, and Cyanobacteria accounted for $21 \%, 9 \%$, and $37 \%$, respectively. In Lake Keluke, it was $1.2 \times 10^{5}$ cells $/ \mathrm{L}, 4.2 \times 10^{5}$ cells $/ \mathrm{L}$, and $2.0 \times 10^{7}$ cells/L. Bacillariophyta accounted for $56 \%, 40 \%$, and $50 \%$ of phytoplankton, and Cyanobacteria accounted for $24 \%, 31 \%$, and $28 \%$ in the spring, summer, and autumn, respectively. In Lake Tuosu, it was $2.9 \times 10^{4}$ cells $/ \mathrm{L}, 6.9 \times 10^{4}$ cells $/ \mathrm{L}$, and $5.6 \times 10^{4}$ cells $/ \mathrm{L}$. Bacillariophyta accounted for $88 \%, 47 \%$, and $82 \%$ of phytoplankton, and Cyanobacteria 
accounted for $9 \%, 22 \%$, and $4 \%$ in the spring, summer, and autumn, respectively. The phytoplankton abundance of Lake Yanghe was $5.2 \times 10^{6}$ cells/L, $2.3 \times 10^{8}$ cells/L, and $3.1 \times 10^{8}$ cells / $\mathrm{L}$ in the spring, summer, and autumn, respectively. The dominant phylum of Lake Yanghe was Cyanobacteria in all three seasons, except for the spring. Chlorophyta accounted for $52 \%$ of phytoplankton in Lake Yanghe in the spring, and Cyanobacteria accounted for $89 \%$ and $98 \%$ of phytoplankton in Lake Yanghe in the summer and autumn, respectively. The dominant phylum of Lake Taihu was Cyanobacteria, which accounted for $35 \%, 44 \%$, and $43 \%$ of phytoplankton in the spring $\left(3.4 \times 10^{8}\right.$ cells $\left./ \mathrm{L}\right)$, summer $\left(2.6 \times 10^{8}\right.$ cells $\left./ \mathrm{L}\right)$, and autumn $\left(1.5 \times 10^{8}\right.$ cells $\left./ \mathrm{L}\right)$, respectively. The dominant species was Microcystis sp. in Lakes Taihu and Yanghe and was Synedra sp. In Lake Qinghai, Lake Keluke, and Lake Tuosu. The Bacillariophyta species (Navicula sp. And Cyclotella sp.); the Chlorophyta species (Monoraphidium sp., Schroederia sp., Oocystis sp., Scenedesmus sp., Chlamydomonas sp., and Closterium sp.); and the Cyanobacteria species (Anabeana sp. and Oscillatoria sp.) were discovered in all five lakes.

Table 1. Means and standard deviations of several water parameters of lakes and inflow rivers of five lakes in China.

\begin{tabular}{|c|c|c|c|c|c|c|}
\hline \multirow{2}{*}{ Lakes and Rivers (n) } & \multirow{2}{*}{ Seasons } & \multicolumn{5}{|c|}{ Water Parameters } \\
\hline & & Temperature $\left({ }^{\circ} \mathrm{C}\right)$ & $\mathrm{pH}$ & Salinity (ppt) & TN (mg/L) & TP (mg/L) \\
\hline \multirow{3}{*}{ Qinghai (6) } & Spring & $17.9 \pm 2.3$ & $9.2 \pm 0.09$ & $10.5 \pm 0.7$ & $2.7 \pm 1.2$ & $0.06 \pm 0.05$ \\
\hline & Summer & $17.5 \pm 0.1$ & $9.2 \pm 0.01$ & $9.5 \pm 1.1$ & $1.8 \pm 0.8$ & $0.01 \pm 0.004$ \\
\hline & Autumn & $7.0 \pm 3.5$ & $9.4 \pm 0.2$ & $8.6 \pm 2.9$ & $3.5 \pm 3.0$ & $0.04 \pm 0.04$ \\
\hline \multirow{4}{*}{ Qinghai (IR) (4) } & Mean & $14.6 \pm 5.5$ & $9.3 \pm 0.1$ & $9.6 \pm 1.8$ & $2.6 \pm 1.8$ & $0.04 \pm 0.04$ \\
\hline & Spring & $12.3 \pm 3.4$ & $8.5 \pm 0.3$ & $0.26 \pm 0.1$ & $7.0 \pm 9.6$ & $0.004 \pm 0.003$ \\
\hline & Summer & $16.5 \pm 0.8$ & $8.6 \pm 0.3$ & $0.28 \pm 0.07$ & $5.8 \pm 4.9$ & $0.02 \pm 0.02$ \\
\hline & Autumn & $8.1 \pm 0.9$ & $8.6 \pm 0.1$ & $0.24 \pm 0.09$ & $7.0 \pm 3.6$ & $0.02 \pm 0.01$ \\
\hline \multirow{5}{*}{ Keluke (5) } & Mean & $12.5 \pm 4.0$ & $8.6 \pm 0.2$ & $0.26 \pm 0.09$ & $6.6 \pm 6.6$ & $0.01 \pm 0.01$ \\
\hline & Spring & $20.6 \pm 4.0$ & $8.5 \pm 0.2$ & $10.2 \pm 20.4$ & $5.1 \pm 8.0$ & $0.05 \pm 0.05$ \\
\hline & Summer & $21.2 \pm 0.8$ & $8.4 \pm 0.3$ & $3.0 \pm 3.8$ & $3.9 \pm 1.1$ & $0.05 \pm 0.03$ \\
\hline & Autumn & $6.0 \pm 0.6$ & $8.2 \pm 0.4$ & $7.7 \pm 11.7$ & $7.5 \pm 7.3$ & $0.06 \pm 0.05$ \\
\hline & Mean & $15.9 \pm 7.6$ & $8.4 \pm 0.3$ & $6.9 \pm 13.1$ & $5.5 \pm 6.0$ & $0.05 \pm 0.04$ \\
\hline \multirow{3}{*}{ Tuosu (3) } & Spring & $20.3 \pm 0.9$ & $9.2 \pm 0.03$ & $22.2 \pm 0.4$ & $0.3 \pm 0.4$ & $0.02 \pm 0.002$ \\
\hline & Summer & $23.1 \pm 1.2$ & $8.8 \pm 0.3$ & $8.5 \pm 7.4$ & $2.0 \pm 0.4$ & $0.02 \pm 0.003$ \\
\hline & Autumn & $10.1 \pm 0.3$ & $9.1 \pm 0.02$ & $13.9 \pm 6.7$ & $1.6 \pm 0.3$ & $0.02 \pm 0.01$ \\
\hline \multirow{3}{*}{ Tuosu (IR)(1) } & Mean & $17.8 \pm 5.9$ & $9.0 \pm 0.2$ & $14.9 \pm 7.8$ & $1.3 \pm 0.8$ & $0.02 \pm 0.008$ \\
\hline & Mean & $16.1 \pm 6.8$ & $8.6 \pm 0.2$ & $0.77 \pm 0.1$ & $2.2 \pm 0.05$ & $0.01 \pm 0.004$ \\
\hline & Spring & $17.1 \pm 0.7$ & $5.7 \pm 0.8$ & $0.17 \pm 0.08$ & $2.7 \pm 0.02$ & $0.01 \pm 0.001$ \\
\hline \multirow[t]{2}{*}{ Yanghe (6) } & Summer & $26.9 \pm 0.7$ & $8.4 \pm 0.2$ & $0.16 \pm 0.005$ & $0.1 \pm 0.01$ & $0.01 \pm 0.002$ \\
\hline & Autumn & $15.5 \pm 0.1$ & $6.5 \pm 0.6$ & $0.18 \pm 0.001$ & $0.5 \pm 0.1$ & $0.03 \pm 0.01$ \\
\hline \multirow{5}{*}{ Taihu (12) } & Mean & $19.8 \pm 5.2$ & $6.9 \pm 1.3$ & $0.17 \pm 0.04$ & $1.1 \pm 1.2$ & $0.02 \pm 0.01$ \\
\hline & Spring & $17.4 \pm 0.2$ & $6.8 \pm 0.3$ & $0.30 \pm 0.04$ & $2.8 \pm 0.7$ & $0.09 \pm 0.11$ \\
\hline & Summer & $30.6 \pm 0.4$ & $7.4 \pm 0.4$ & $0.24 \pm 0.03$ & $0.6 \pm 0.5$ & $0.01 \pm 0.003$ \\
\hline & Autumn & $23 \pm 0.4$ & $6.9 \pm 0.3$ & $0.22 \pm 0.02$ & $0.5 \pm 0.4$ & $0.04 \pm 0.03$ \\
\hline & Mean & $23.7 \pm 5.5$ & $7.0 \pm 0.4$ & $0.25 \pm 0.04$ & $1.3 \pm 1.2$ & $0.05 \pm 0.07$ \\
\hline
\end{tabular}

$\mathrm{n}$ indicates the number of sampling sites; IR indicates inflow rivers.

There were clear differences in phytoplankton biodiversity of the five lakes. In Lake Qinghai, the phytoplankton biodiversity was $0.19 \pm 0.30,0.38 \pm 0.37$, and $0.39 \pm 0.46$ in the spring, summer, and autumn, respectively. In Lake Keluke, the phytoplankton biodiversity was $0.87 \pm 0.56,0.75 \pm 0.67$, and $0.72 \pm 0.45$, respectively. In Lake Tuosu, the phytoplankton biodiversity was $0.41 \pm 0.39,1.25 \pm 0.19$, and $0.66 \pm 0.30$ in the spring, summer, and autumn, respectively. In Lake Yanghe, the phytoplankton biodiversity was $0.91 \pm 0.18,0.10 \pm 0.07$, and $0.34 \pm 0.43$ in the spring, summer, and autumn, respectively. In Lake Taihu, the phytoplankton biodiversity was $0.38 \pm 0.33,0.51 \pm 0.37$, and $0.41 \pm 0.39$, respectively. 


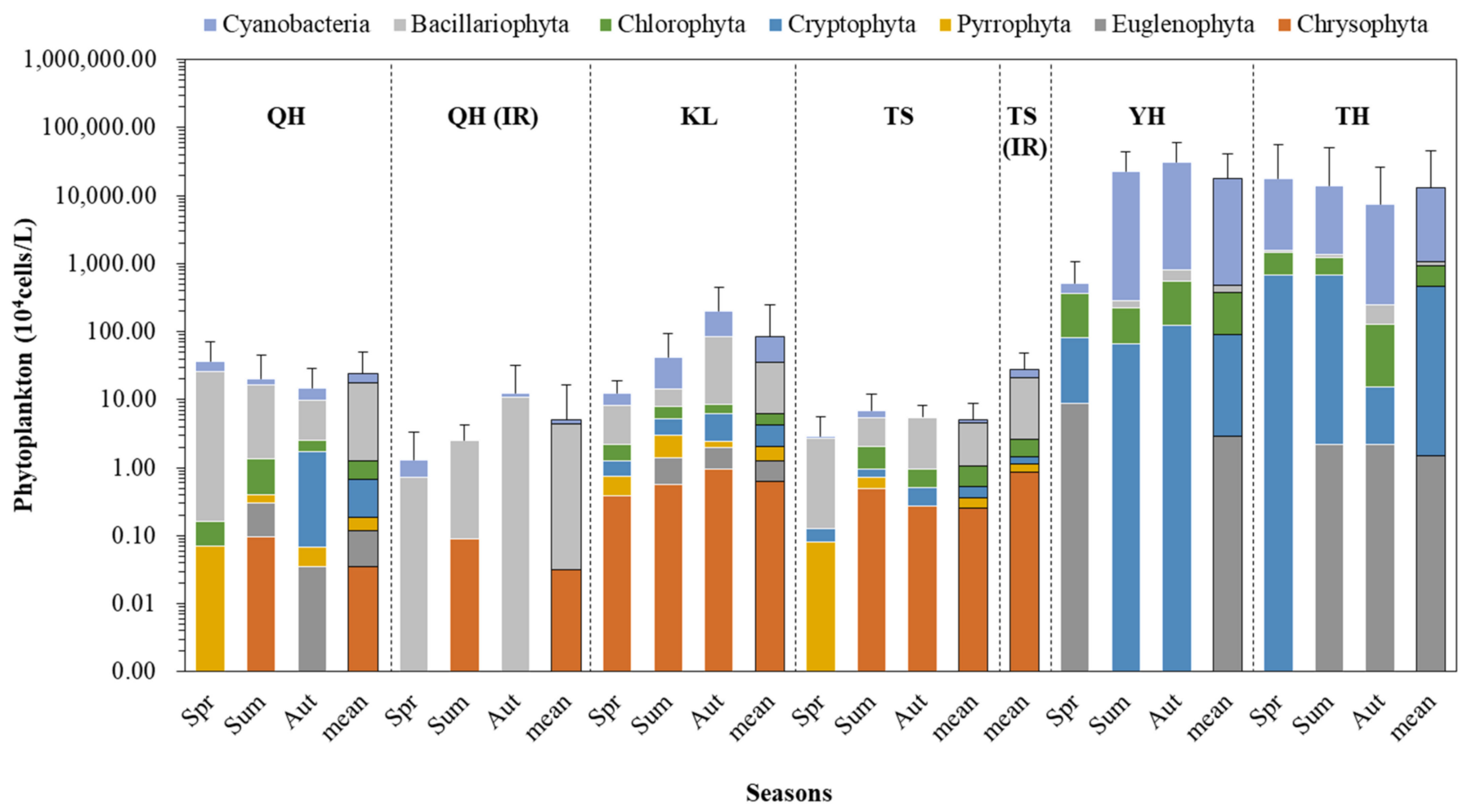

Figure 2. Phytoplankton composition based on the abundance in different seasons in Lake Qinghai (QH), Lake Keluke (KL), Lake Tuosu (TS), Lake Yanghe (YH), Lake Taihu (TH), and the inflow rivers (IR) of Lake Qinghai and Lake Tuosu. The error bars indicate the standard deviations of phytoplankton abundance in each lake.

\subsection{Correlations between Water Parameters and Phytoplankton in the Five Lakes}

The phytoplankton had significant relationships with temperature based on the annual average data from Lake Qinghai, Lake Keluke, Lake Tuosu, Lake Yanghe, and Lake Taihu (Figure 3). Bacillariophyta, Cyanobacteria, Chlorophyta, and phytoplankton abundance had significantly positive relationships with temperature under $R^{2}=0.59,0.70$, 0.71 , and $0.74(p<0.05)$. Additionally, the ratio of Bacillariophyta/phytoplankton had a significantly negative relationship with temperature $(p<0.01)$, and the ratio of Cyanobacteria/phytoplankton had a significantly positive relationship with temperature $(p<0.01)$.

The phytoplankton had a significant relationship with $\mathrm{pH}$ based on the annual average data from the five lakes in China (Figure 4). Bacillariophyta, Cyanobacteria, Chlorophyta, and phytoplankton abundance had significantly negative relationships with $\mathrm{pH}$ under $\mathrm{R}^{2}=0.58,0.82,0.80$, and $0.81(p<0.01)$. Additionally, the ratio of Bacillariophyta/phytoplankton had a significantly positive relationship with the $\mathrm{pH}(p<0.01)$. The ratio of Cyanobacteria/phytoplankton had a significantly negative relationship with the $\mathrm{pH}$ $(p<0.01)$. Additionally, phytoplankton had a significant relationship with salinity based on the annual average data from the five lakes in China (Figure 5). Bacillariophyta, Cyanobacteria, Chlorophyta, and phytoplankton abundance had significant negative relationships with salinity $(p<0.05)$ (Figure 5). 

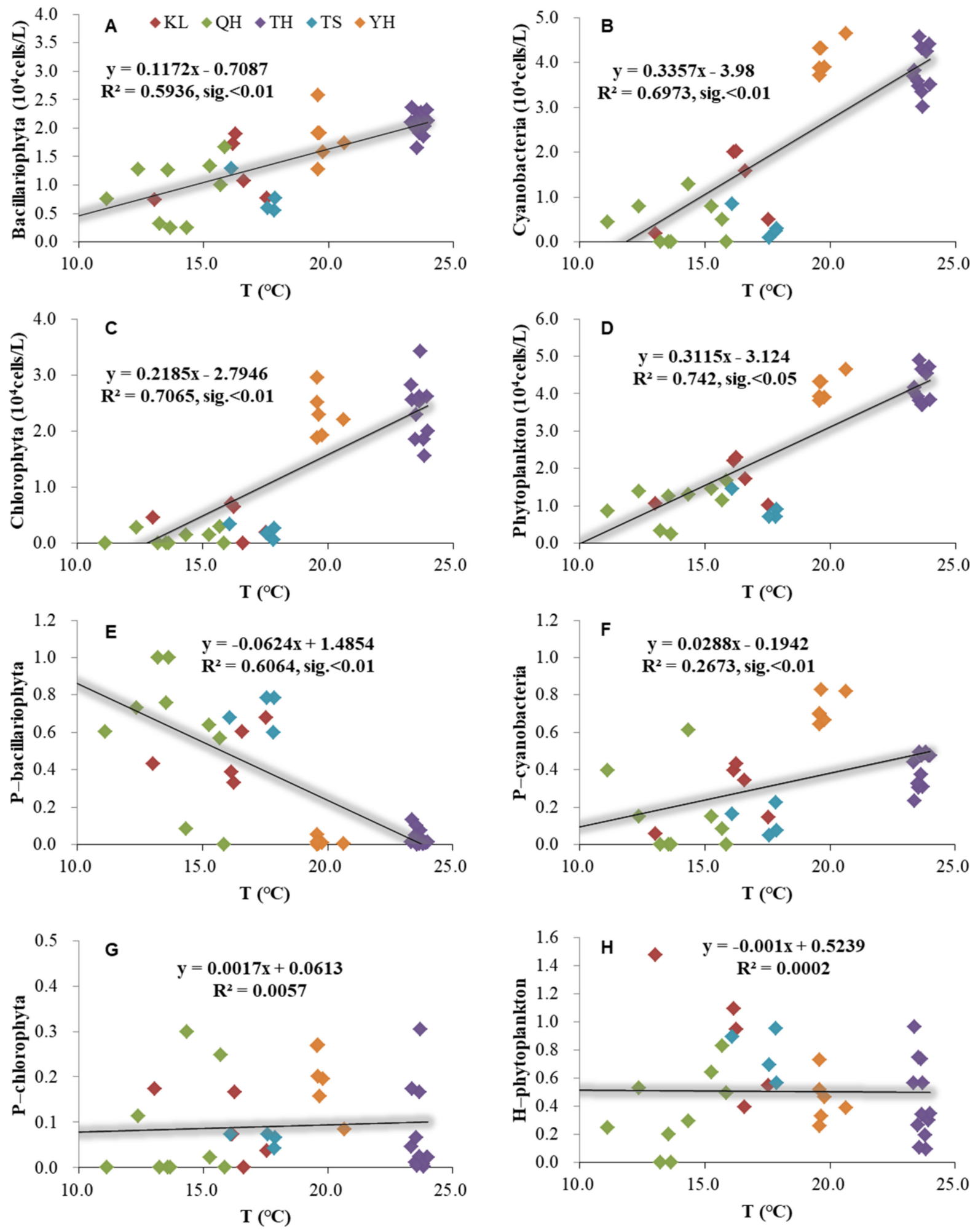

Figure 3. Relationships between temperature $(\mathrm{T})$ and phytoplankton based on the annual average data of each site of Lake Qinghai, Lake Keluke, Lake Tuosu, Lake Yanghe, and Lake Taihu. (A-D) showed the relationships between $\mathrm{T}$ and phytoplankton, and $(\mathbf{E}-\mathbf{H})$ showed the relationships between $\mathrm{T}$ and phytoplankton composition. Bacillariophyta, Chlorophyta, Cyanobacteria, and phytoplankton abundance were transformed by $\log (X+1)$. P-i indicates the $i /$ phytoplankton ratio based on abundance. H-phytoplankton represents the biodiversity of phytoplankton. 

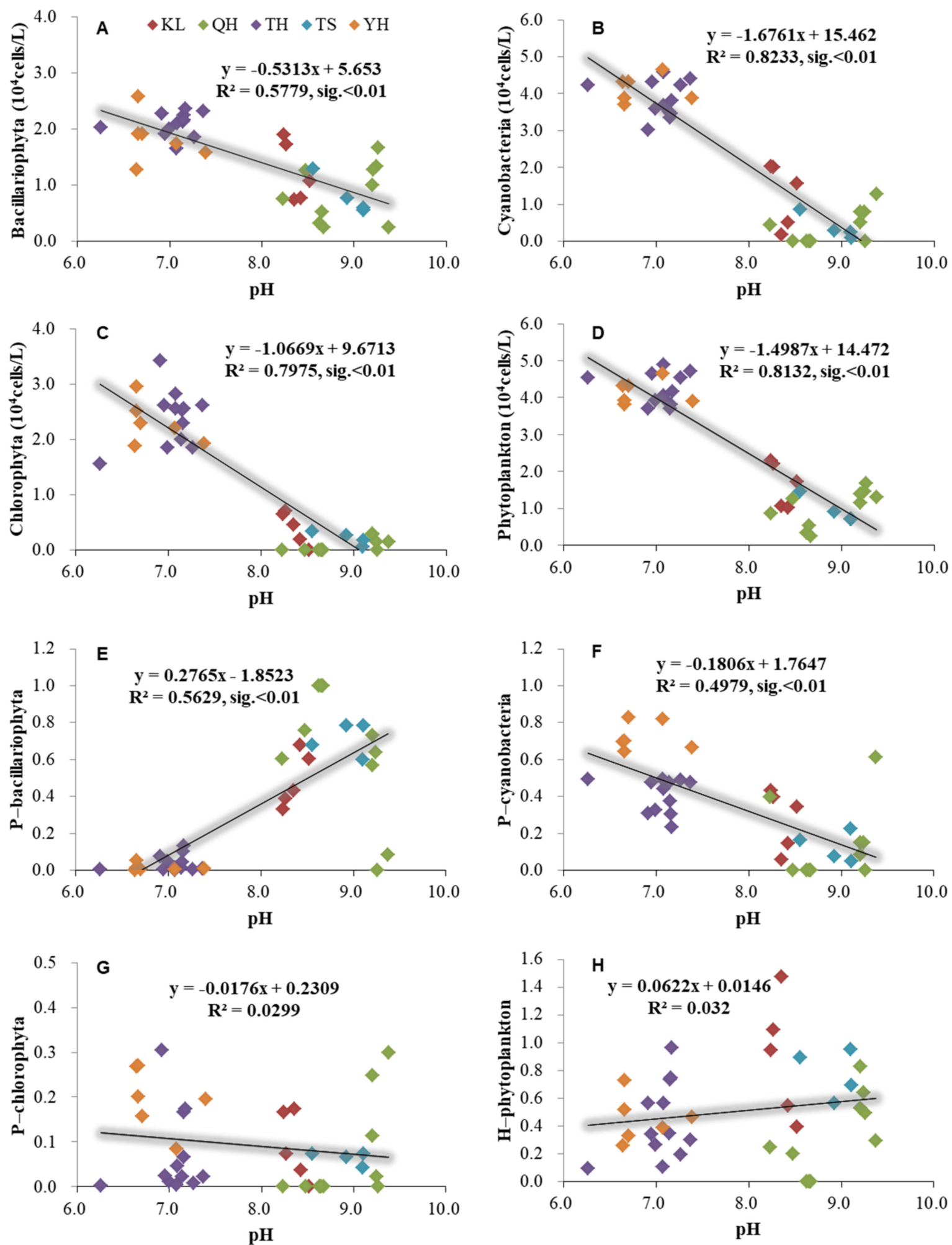

Figure 4. Relationships between $\mathrm{pH}$ and phytoplankton based on the annual average data of each site of Lake Qinghai, Lake Keluke, Lake Tuosu, Lake Yanghe, and Lake Taihu. (A-D) showed the relationships between $\mathrm{pH}$ and phytoplankton, and $(\mathbf{E}-\mathbf{H})$ showed the relationships between $\mathrm{pH}$ and phytoplankton composition. Bacillariophyta, Chlorophyta, Cyanobacteria, and phytoplankton abundance were transformed by $\log (X+1)$. P-i indicates the $\mathrm{i} /$ phytoplankton ratio based on abundance. H-phytoplankton represents the biodiversity of phytoplankton. 

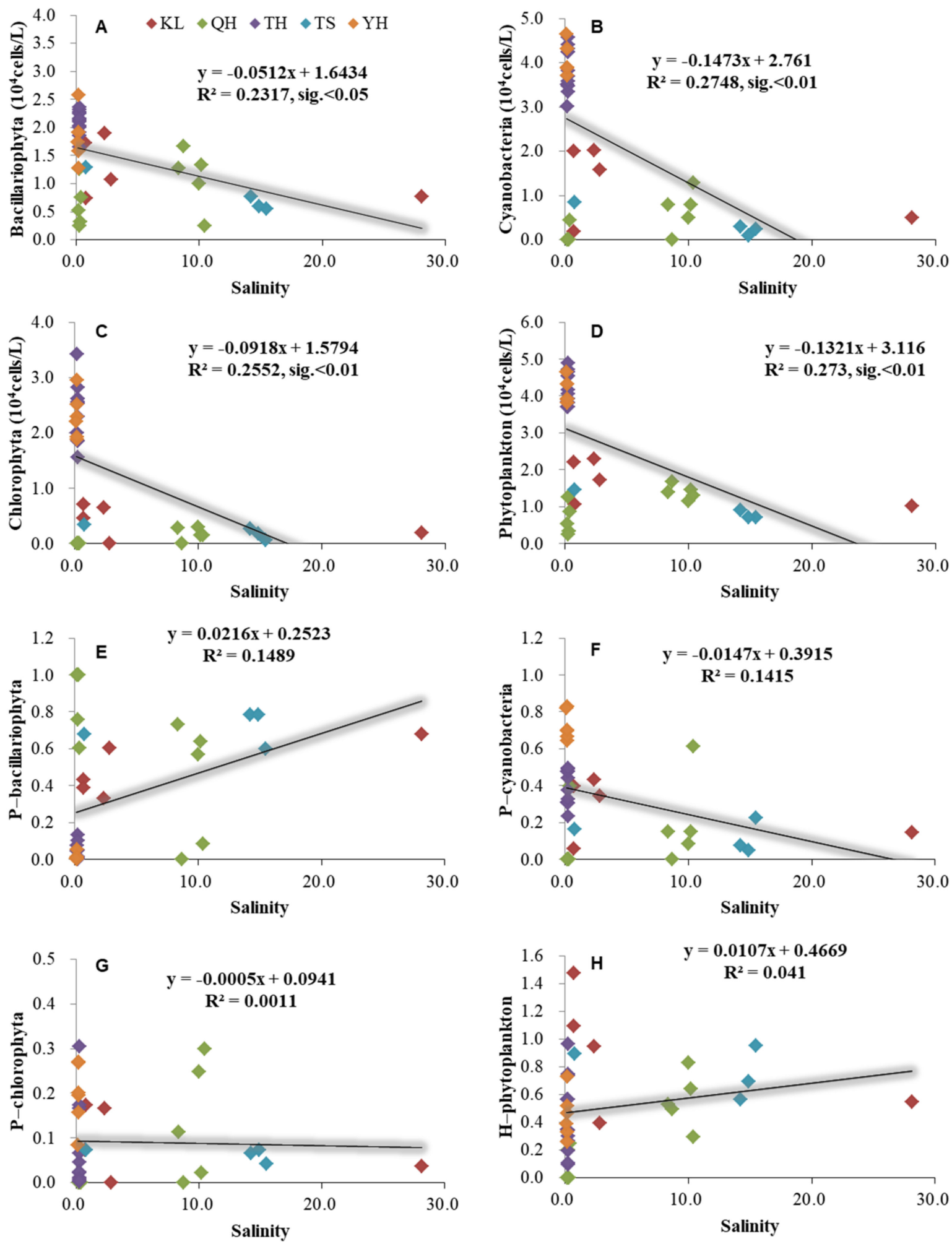

Figure 5. Relationships between salinity and phytoplankton based on the annual average data of each site of Lake Qinghai, Lake Keluke, Lake Tuosu, Lake Yanghe, and Lake Taihu. (A-D) showed the relationships between salinity and phytoplankton, and $(\mathbf{E}-\mathbf{H})$ showed the relationships between salinity and phytoplankton composition. Bacillariophyta, Chlorophyta, Cyanobacteria, and phytoplankton abundance were transformed by $\log (X+1)$. P-i indicates the i/phytoplankton ratio based on abundance. H-phytoplankton represents the biodiversity of phytoplankton. 


\section{Discussion}

The temperature was one of the most essential factors regulating the growth of phytoplankton [1,7]. In the present study, phytoplankton abundance had a significantly positive relationship with water temperature. Additionally, the lakes with higher temperatures generally possessed higher phytoplankton abundance, such as Lake Taihu and Lake Yanghe. Thus, the temperature was a crucial factor promoting the growth of phytoplankton in the five lakes. Previous studies demonstrated that higher temperatures favored the growth of Cyanobacteria [10-12]. This is consistent with the result in the present study that the lakes with higher temperatures generally had higher Cyanobacteria abundance and a Cyanobacteria/phytoplankton ratio. Lake Taihu and Lake Yanghe had higher average water temperatures compared to Lake Qinghai, Lake Keluke, and Lake Tuosu. Hence, Lake Taihu and Lake Yanghe had higher average Cyanobacteria abundance and a higher Cyanobacteria/phytoplankton ratio than Lake Qinghai, Lake Keluke, and Lake Tuosu. Additionally, the Cyanobacteria/phytoplankton ratio exhibited a significantly positive relationship with temperature.

The nutrients were another vital factor regulating the growth of phytoplankton. In the present study, TN had a high concentration in the five lakes, and there were not many differences in TP concentration. A previous study revealed that the growth of the dominant phytoplankton was not nutrient-limited under P enrichment $\geq 0.20 \mathrm{mg} \cdot \mathrm{L}^{-1}(\mathrm{P})$ and $\mathrm{N}$ enrichment $\geq 0.80 \mathrm{mg} \cdot \mathrm{L}^{-1}(\mathrm{~N})$ [8]. Therefore, the growth of the dominant phytoplankton in all the lakes was not $\mathrm{N}$-limited. In other words, $\mathrm{TN}$ does not shape the differences in phytoplankton abundance in the five lakes. Phosphorus is one of the limiting factors for phytoplankton growth in all five lakes, since the TP was much lower than $0.20 \mathrm{mg} \cdot \mathrm{L}^{-1}$ in those lakes. Thus, TP does not shape the differences in phytoplankton abundance in the five lakes. However, the high nutrient level in Lake Qinghai, Lake Keluke, and Lake Tuosu, located in the Tibetan Plateau, should be stressed under climate change. In recent years, the lakes in the Tibetan Plateau are undergoing an increase in temperature and precipitation. The rising temperature may result in a blooming of phytoplankton, especially Cyanobacteria, in those lakes with enough nutrients. The increase in precipitation may induce more nutrient input, especially TP, in the lakes of the Tibetan Plateau. This has been confirmed in Lake Qinghai that the TP increased but TN decreased in the inflowing rivers, contributing to the alleviation of the P deficiency in Lake Qinghai and the promotion of the growth of phytoplankton [31].

In the present study, the $\mathrm{pH}$ had significantly negative relationships with Bacillariophyta, Cyanobacteria, Chlorophyta, and phytoplankton. This may be caused by a relatively high phytoplankton abundance and low $\mathrm{pH}$ in Lake Taihu and Lake Yanghe, as well as relatively low phytoplankton abundance and high $\mathrm{pH}$ in other lakes. A previous study suggested that the natural phytoplankton biomass decreased in high $\mathrm{pH}$ (9.5) incubation, while the phytoplankton biomass increased in $\mathrm{pH}$ 8-9 incubation [43]. In Lake Taihu and Lake Yanghe, the mean $\mathrm{pH}$ was low ( $\mathrm{pH}=7.0$ and 6.9 , respectively), and the phytoplankton could grow well if the $\mathrm{pH}$ increased from 7.0 to 9.0, since the blooming of the phytoplankton was associated with an increase in $\mathrm{pH}$ [44]. This would be explained by the blooming of the phytoplankton, which depletes the dissolved $\mathrm{CO}_{2}$ concentration and, therefore, results in an increase in $\mathrm{pH}$ [45-47]. This is consistent with previous studies that the $\mathrm{pH}$ increased with increasing the cell densities of Cyanobacteria, and the Cyanobacteria blooms were associated with high $\mathrm{pH}[44,48,49]$. In Lake Yanghe, the Cyanobacteria accounted for $98 \%$ of the total phytoplankton when the Cyanobacteria abundance reached $2.2 \times 10^{8}$ cells $/ \mathrm{L}$, and the $\mathrm{pH}$ reached 8.7 in the summer. However, the high $\mathrm{pH}$ may not favor the growth of phytoplankton. Additionally, Microcystis aeruginosa and Scenedesmus quadricauda were at the stationary phase under high $\mathrm{pH}$ values (10.0), and both algae resumed growing when the $\mathrm{pH}$ was decreased using $\mathrm{HCl}$ [50]. Additionally, Touloupakis et al. [51] confirmed that the light conversion efficiency of Cyanobacteria decreased linearly with the increase in $\mathrm{pH}$ at a range of 7.5-11. Therefore, a high $\mathrm{pH}\left(\mathrm{high} \mathrm{OH}^{-}\right)$could cause an adverse effect on the 
phytoplankton growth [52], and the phytoplankton cannot grow well in Lake Qinghai and Lake Tuosu at high $\mathrm{pH}$ values (both mean $\mathrm{pH} \geq 9.0$ ).

High salinity was an adverse factor for phytoplankton growth, since it can cause oxidative stress to algal cells, resulting in cell death $[53,54]$. This is consistent with the results in the present study. The Bacillariophyta, Cyanobacteria, Chlorophyta, and phytoplankton all had significantly negative relationships with salinity. However, the low phytoplankton abundance in some brackish lakes should not be simply attributed to high salinity. Recently, more and more studies have revealed that freshwater phytoplankton blooms occur in brackish waters [32,33]. Additionally, indoor cultivation has implied that the freshwater strain Microcystis aeruginosa, a typical blooming species, acclimated to a salinity gradient that could reach 7.5 [52]. In the present study, Lake Keluke had a salinity lower than the maximum tolerance salinity based on indoor cultivation but a low phytoplankton abundance. Hence, the low phytoplankton abundance of Lake Keluke should not be simply attributed to high salinity. In Lake Tuosu, nevertheless, the salinity reached $11.3 \pm 9.2$ and could have an adverse effect on many phytoplankton species.

The factors elaborated above are imperative to phytoplankton, especially for phytoplankton of the alpine lakes in the Tibetan Plateau. The lakes in the Tibetan Plateau experience a warm and wet climate [55,56], leading to changes in the water temperature, nutrients, and salinity and eventually facilitating the growth of phytoplankton [57]. Particularly, phytoplankton blooms may occur in those brackish lakes with enough nutrients under climate change. The brackish lakes in the Tibetan Plateau should receive priority for management, since some rare fish and birds live in those lakes. Their simple and fragile food chains could be altered under climate change. Buffer zones may be an effective approach for those alpine lakes to alleviate diffusive pollutions from agriculture and livestock.

\section{Conclusions}

The phytoplankton community was dominated by Bacillariophyta, followed by Cyanobacteria and Chlorophyta in the alpine lakes, including Lake Qinghai, Lake Keluke, and Lake Tuosu. It was dominated by Cyanobacteria, followed by Chlorophyta and Bacillariophyta in Lake Yanghe. Additionally, it was dominated by Cyanobacteria, followed by Chlorophyta and Cryptophyta in Lake Taihu. The temperature was a crucial factor influencing the growth of Cyanobacteria, Chlorophyta, and Bacillariophyta, especially Cyanobacteria and Chlorophyta. The $\mathrm{pH}$ had significantly negative relationships with Cyanobacteria, Chlorophyta, and Bacillariophyta. Moreover, it could be a strongly negative factor for phytoplankton growth in alpine lakes. Salinity had significantly negative relationships with Cyanobacteria, Chlorophyta, and Bacillariophyta. It was also an adverse factor for phytoplankton when it was very high.

Author Contributions: J.J.: conceptualization, methodology, investigation, writing-original draft preparation, writing-review and editing, and funding acquisition; Q.C.: conceptualization and writing-review and editing resources; H.R. investigation, writing-original draft preparation, and writing — review and editing; R.L. writing—original draft preparation, writing—review and editing, and funding acquisition, H.H.: investigation and writing - original draft preparation; and P.G.: investigation and writing - original draft preparation. All authors have read and agreed to the published version of the manuscript.

Funding: This research was funded by the Project of Qinghai Science \& Technology Department (2018-ZJ-958Q) and the National Natural Science Foundation of China (No. 42167012), as well as the Suzhou Minsheng Science and Technology Development Program Project (No. SS201838).

Data Availability Statement: The data presented in this study are available on request from the corresponding author. The data are not publicly available due to privacy.

Conflicts of Interest: The authors declare no conflict of interest. 


\section{References}

1. Cao, J.; Hou, Z.; Li, Z.; Chu, Z.; Yang, P.; Zheng, B. Succession of phytoplankton functional groups and their driving factors in a subtropical plateau lake. Sci. Total Environ. 2018, 631-632, 1127-1137. [CrossRef] [PubMed]

2. Jia, J.; Shi, W.; Chen, Q.; Lauridsen, T.L. Spatial and temporal variations reveal the response of zooplankton to cyanobacteria. Harmful Algae 2017, 64, 63-73. [CrossRef]

3. Jia, J.; Luo, W.; Lu, Y.; Giesy, J.P. Bioaccumulation of microcystins (MCs) in four fish species from Lake Taihu, China: Assessment of risks to humans. Sci. Total Environ. 2014, 487, 224-232. [CrossRef] [PubMed]

4. Su, X.; Steinman, A.D.; Oudsema, M.; Hassett, M.; Xie, L. The influence of nutrients limitation on phytoplankton growth and microcystins production in Spring Lake, USA. Chemosphere 2019, 234, 34-42. [CrossRef] [PubMed]

5. Yang, Y.; Pan, J.; Han, B.-P.; Naselli-Flores, L. The effects of absolute and relative nutrient concentrations (N/P) on phytoplankton in a subtropical reservoir. Ecol. Indic. 2020, 115, 106466. [CrossRef]

6. Derot, J.; Jamoneau, A.; Teichert, N.; Rosebery, J.; Morin, S.; Laplace-Treyture, C. Response of phytoplankton traits to environmental variables in French lakes: New perspectives for bioindication. Ecol. Indic. 2020, 108, 105659. [CrossRef]

7. Li, J.; Ma, R.; Xue, K.; Loiselle, S. Drivers to spatial and temporal dynamics of column integrated phytoplankton biomass in the shallow lake of Chaohu, China. Ecol. Indic. 2020, 109, 105812. [CrossRef]

8. Xu, H.; Paerl, H.W.; Qin, B.; Zhu, G.; Gao, G. Nitrogen and phosphorus inputs control phytoplankton growth in eutrophic Lake Taihu, China. Limnol. Oceanogr. 2010, 55, 420-432. [CrossRef]

9. Vrede, T.; Ballantyne, A.; Mille-Lindblom, C.; Algesten, G.; Gudasz, C.; Lindahl, S.; Brunberg, A.K. Effects of N:P loading ratios on phytoplankton community composition, primary production and $\mathrm{N}$ fixation in a eutrophic lake. Freshwater Biol. 2009, 54, 331-344. [CrossRef]

10. Johnk, K.D.; Huisman, J.; Sharples, J.; Sommeijer, B.; Visser, P.M.; Stroom, J.M. Summer heatwaves promote blooms of harmful cyanobacteria. Glob. Chang. Biol. 2008, 14, 495-512. [CrossRef]

11. Zhang, M.; Qin, B.; Yu, Y.; Yang, Z.; Shi, X.; Kong, F. Effects of temperature fluctuation on the development of cyanobacterial dominance in spring: Implication of future climate change. Hydrobiologia 2016, 763, 135-146. [CrossRef]

12. Kosten, S.; Huszar, V.L.M.; Bécares, E.; Costa, L.S.; Donk, E.; Hansson, L.-A.; Jeppesen, E.; Kruk, C.; Lacerot, G.; Mazzeo, N.; et al Warmer climates boost cyanobacterial dominance in shallow lakes. Glob. Chang. Biol. 2012, 18, 118-126. [CrossRef]

13. Schindler, D.W. Eutrophication and Recovery in Experimental Lakes-Implications for Lake Management. Science 1974, 184, 897-899. [CrossRef] [PubMed]

14. Hecky, R.E.; Kilham, P. Nutrient limitation of phytoplankton in fresh-water and marine environments-A review of recentevidence on the effects of enrichment. Limnol. Oceanogr. 1988, 33, 796-822.

15. Nixon, S.W. Coastal marine eutrophication-A definition, social causes, and future concerns. Ophelia 1995, 41, 199-219. [CrossRef]

16. Lv, J.; Wu, H.; Chen, M. Effects of nitrogen and phosphorus on phytoplankton composition and biomass in 15 subtropical, urban shallow lakes in Wuhan, China. Limnologica 2011, 41, 48-56. [CrossRef]

17. Dokulil, M.T.; Teubner, K. Cyanobacterial dominance in lakes. Hydrobiologia 2000, 438, 1-12. [CrossRef]

18. Conley, D.J.; Paerl, H.W.; Howarth, R.W.; Boesch, D.F.; Seitzinger, S.P.; Havens, K.E.; Lancelot, C.; Likens, G.E. ECOLOGY Controlling Eutrophication: Nitrogen and Phosphorus. Science 2009, 323, 1014-1015. [CrossRef]

19. Paerl, H.W.; Fulton, R.S. Ecology of Harmful Marine Algae; Springer: Berlin, Germany, 2006; pp. $95-107$.

20. Paerl, H.W.; Huisman, J. Climate-Blooms like it hot. Science 2008, 320, 57-58. [CrossRef]

21. Fernandez, C.; Estrada, V.; Parodi, E.R. Factors Triggering Cyanobacteria Dominance and Succession During Blooms in a Hypereutrophic Drinking Water Supply Reservoir. Water Air Soil Pollut. 2015, 226, 1-13. [CrossRef]

22. Gobler, C.J.; Davis, T.W.; Coyne, K.J.; Boyer, G.L. Interactive influences of nutrient loading, zooplankton grazing, and microcystin synthetase gene expression on cyanobacterial bloom dynamics in a eutrophic New York lake. Harmful Algae 2007, 6, 119-133. [CrossRef]

23. Sunda, W.G.; Graneli, E.; Gobler, C.J. Positive feedback and the development and persistence of ecosystem disruptive algal blooms. J. Phycol. 2006, 42, 963-974. [CrossRef]

24. Harke, M.J.; Davis, T.W.; Watson, S.B.; Gobler, C.J. Nutrient-Controlled Niche Differentiation of Western Lake Erie Cyanobacterial Populations Revealed via Metatranscriptomic Surveys. Environ. Sci. Technol. 2016, 50, 604-615. [CrossRef]

25. Davis, T.W.; Harke, M.J.; Marcoval, M.A.; Goleski, J.; Orano-Dawson, C.; Berry, D.L.; Gobler, C.J. Effects of nitrogenous compounds and phosphorus on the growth of toxic and non-toxic strains of Microcystis during cyanobacterial blooms. Aquat. Microb. Ecol. 2010, 61, 149-162. [CrossRef]

26. Agrawal, M.K.; Bagchi, D.; Bagchi, S.N. Acute inhibition of protease and suppression of growth in zooplankter, Moina macrocopa, by Microcystis blooms collected in Central India. Hydrobiologia 2001, 464, 37-44. [CrossRef]

27. Agrawal, M.K.; Zitt, A.; Bagchi, D.; Weckesser, J.; Bagchi, S.N.; von Elert, E. Characterization of proteases in guts of Daphnia magna and their inhibition by Microcystis aeruginosa PCC 7806. Environ. Toxicol. 2005, 20, 314-322. [CrossRef] [PubMed]

28. O'Neil, J.M.; Davis, T.W.; Burford, M.A.; Gobler, C.J. The rise of harmful cyanobacteria blooms: The potential roles of eutrophication and climate change. Harmful Algae 2012, 14, 313-334. [CrossRef]

29. Schindler, D.W.; Hecky, R.E.; Findlay, D.L.; Stainton, M.P.; Parker, B.R.; Paterson, M.J.; Beaty, K.G.; Lyng, M.; Kasian, S.E.M. Eutrophication of lakes cannot be controlled by reducing nitrogen input: Results of a 37-year whole-ecosystem experiment. Proc. Natl. Acad. Sci. USA 2008, 105, 11254-11258. [CrossRef] 
30. Tolotti, M.; Thies, H.; Nickus, U.; Psenner, R. Temperature modulated effects of nutrients on phytoplankton changes in a mountain lake. Hydrobiologia 2012, 698, 61-75. [CrossRef]

31. Ren, Z.; Niu, D.; Ma, P.; Wang, Y.; Fu, H.; Elser, J.J. Cascading influences of grassland degradation on nutrient limitation in a high mountain lake and its inflow streams. Ecology 2019, 100, e02755. [CrossRef]

32. Preece, E.P.; Hardy, F.J.; Moore, B.C.; Bryan, M. A review of microcystin detections in Estuarine and Marine waters: Environmental implications and human health risk. Harmful Algae 2017, 61, 31-45. [CrossRef]

33. Von Alvensleben, N.; Magnusson, M.; Heimann, K. Salinity tolerance of four freshwater microalgal species and the effects of salinity and nutrient limitation on biochemical profiles. J. Appl. Phycol. 2015, 28, 861-876. [CrossRef]

34. Zhang, D.W.; Xie, P.; Liu, Y.Q.; Qiu, T. Transfer, distribution and bioaccumulation of microcystins in the aquatic food web in Lake Taihu, China, with potential risks to human health. Sci. Total Environ. 2009, 407, 2191-2199. [CrossRef]

35. Jin, X.; Hu, X. A comprehensive plan for treating the major polluted regions of Lake Taihu, China. Lakes Reserv. Res. Manag. 2003, 8, 217-230. [CrossRef]

36. Zhang, X.; Lin, C.; Zhou, X.; Lei, K.; Guo, B.; Cao, Y.; Lu, S.; Liu, X.; He, M. Concentrations, fluxes, and potential sources of nitrogen and phosphorus species in atmospheric wet deposition of the Lake Qinghai Watershed, China. Sci. Total Environ. 2019, 682, 523-531. [CrossRef] [PubMed]

37. Cao, Y.; Lin, C.; Zhang, X.; Liu, X.; He, M.; Ouyang, W. Distribution, source, and ecological risks of polycyclic aromatic hydrocarbons in Lake Qinghai, China. Environ. Pollut. 2020, 266 Pt 1, 115401. [CrossRef]

38. Ding, Z.; Zhang, J.; Yang, P.; Zhou, S.; Zhang, Y. Comparison of sediment proxies of cores and their environmental significance at different locations of Lake Toson in Qaidam Basin. J. Lake Sci. 2020, 32, 259-270.

39. National Environmental Protection Bureau. Standard Methods for the Examination of Water and Wastewater (Version 4); China Environmental Science Publish Press: Beijing, China, 2002. (In Chinese)

40. Watanabe, M.M.; Kaya, K.; Takamura, N. Fate of the toxic cyclic heptapeptides, the microcystins, from blooms of Microcystis (cyanobacteria) in a hypertrophic lake. J. Phycol. 1992, 28, 761-767. [CrossRef]

41. Song, L.R.; Chen, W.; Peng, L.; Wan, N.; Gan, N.Q.; Zhang, X.M. Distribution and bioaccumulation of microcystins in water columns: A systematic investigation into the environmental fate and the risks associated with microcystins in Meiliang Bay, Lake Taihu. Water Res. 2007, 41, 2853-2864. [CrossRef]

42. Jeppesen, E.; Jensen, J.P.; Sondergaard, M.; Lauridsen, T.; Landkildehus, F. Trophic structure, species richness and biodiversity in Danish lakes: Changes along a phosphorus gradient. Freshwater Biol. 2000, 45, 201-218. [CrossRef]

43. Ji, X.; Verspagen, J.M.H.; Stomp, M.; Huisman, J. Competition between cyanobacteria and green algae at low versus elevated CO2: Who will win, and why? J. Exp. Bot. 2017, 68, 3815-3828. [CrossRef] [PubMed]

44. Kranz, S.A.; Gladrow, D.W.; Nehrke, G.; Langer, G.; Rosta, B. Calcium carbonate precipitation induced by the growth of the marine cyanobacteriaTrichodesmium. Limnol. Oceanogr. 2010, 55, 2563-2569. [CrossRef]

45. Talling, J.F. The Depletion of Carbon Dioxide from Lake Water by Phytoplankton. J. Ecol. 1976, 64, 79-121. [CrossRef]

46. Balmer, M.B.; Downing, J.A. Carbon dioxide concentrations in eutrophic lakes: Undersaturation implies atmospheric uptake. Inland Waters 2011, 1, 125-132. [CrossRef]

47. Verschoor, A.M.; Van Dijk, M.A.; Huisman, J.; Van Donk, E. Elevated CO2 concentrations affect the elemental stoichiometry and species composition of an experimental phytoplankton community. Freshwater Biol. 2013, 58, 597-611. [CrossRef]

48. Liu, X.; Lu, X.H.; Chen, Y.W. The effects of temperature and nutrient ratios on Microcystis blooms in Lake Taihu, China: An 11-year investigation. Harmful Algae 2011, 10, 337-343. [CrossRef]

49. Hörnström, E. Phytoplankton in 63 limed lakes in comparison with the distribution in 500 untreated lakes with varying pH. Hydrobiologia 2002, 470, 115-126. [CrossRef]

50. Ma, Z.; Chu, Z.; Hu, X.; Jin, X.; Zhang, G. The Effect of pH on Competition of M. aeruginosa and S. quadricauda at Different Phosphorus Mass Concentration. Res. Environ. Sci. 2005, 18, 30-33.

51. Touloupakis, E.; Cicchi, B.; Silva Benavides, A.M.; Torzillo, G. Effect of high pH on growth of Synechocystis sp PCC 6803 cultures and their contamination by golden algae (Poterioochromonas sp.). Appl. Microbiol. Biotechnol. 2016, 100, 1333-1341. [CrossRef]

52. Georges des Aulnois, M.; Roux, P.; Caruana, A.; Réveillon, D.; Briand, E.; Hervé, F.; Savar, V.; Bormans, M.; Amzil, Z. Physiological and Metabolic Responses of Freshwater and Brackish-Water Strains of Microcystis aeruginosa Acclimated to a Salinity Gradient: Insight into Salt Tolerance. Appl. Environ. Microbiol. 2019, 85, e01614-19. [CrossRef]

53. Ross, C.; Warhurst, B.C.; Brown, A.; Huff, C.; Ochrietor, J.D. Mesohaline conditions represent the threshold for oxidative stress, cell death and toxin release in the cyanobacterium Microcystis aeruginosa. Aquat. Toxicol. 2019, 206, 203-211. [CrossRef] [PubMed]

54. Affenzeller, M.J.; Darehshouri, A.; Andosch, A.; Lutz, C.; Lutz-Meindl, U. Salt stress-induced cell death in the unicellular green alga Micrasterias denticulata. J. Exp. Bot. 2009, 60, 939-954. [CrossRef] [PubMed]

55. Yao, T.; Yu, W. Recent Glacial Retreat and Its Impact on Hydrological Processes on the Tibetan Plateau, China, and Surrounding Regions. Arct. Antarct. Alp. Res. 2007, 39, 642-650. [CrossRef]

56. Lin, Q.; Xu, L.; Hou, J.; Liu, Z.; Jeppesen, E.; Han, B.P. Responses of trophic structure and zooplankton community to salinity and temperature in Tibetan lakes: Implication for the effect of climate warming. Water Res. 2017, 124, 618-629. [CrossRef]

57. Jeppesen, E.; Meerhoff, M.; Holmgren, K.; González-Bergonzoni, I.; Teixeira-de Mello, F.; Declerck, S.A.J.; De Meester, L.; Søndergaard, M.; Lauridsen, T.L.; Bjerring, R.; et al. Impacts of climate warming on lake fish community structure and potential effects on ecosystem function. Hydrobiologia 2010, 646, 73-90. [CrossRef] 